\title{
Wine consumers' environmental knowledge and attitudes: Influence on willingness to purchase
}

\author{
Nelson Barber' \\ Christopher Taylor ${ }^{2}$ \\ Sandy Strick ${ }^{3}$ \\ 'College of Human Sciences, Box \\ 4I240 Texas Tech University, Lubbock, \\ TX, USA; ${ }^{2}$ School of Business, Eastern \\ New Mexico University, Portales, NM, \\ USA; ${ }^{3}$ School of Hotel, Restaurant, \\ and Tourism Management, University \\ of South Carolina, Columbia, SC, USA
}

Correspondence: Nelson Barber

College of Human Sciences, Box 4I 240

Texas Tech University, Lubbock,

TX 79409, USA

Tel + I 8067423068

Fax +l 8067423068

Email nelsonbarber@msn.com

\begin{abstract}
The last two decades have witnessed a dramatic increase in environmental consciousness worldwide. Consumers are now changing their behavior to integrate environmental considerations into lifestyle choices. This change includes consumers' purchasing decisions based upon how well products satisfy their needs and how these products affect the natural environment. In some cases, consumers are willing to pay a premium for environmentally friendly products. Marketing professes to serve the benefit of the public by informing them of the availability of goods and services that will advance their quality of life. However, this is only true if marketing's communication approach and methods of promotion aid in informing, educating, and channeling the needs of current and future consumers toward "green" products and services. Using wine as the product, the purpose of this study is to determine the relationship of a consumer's involvement with a product and the environment, their knowledge of environmental issues and attitudes toward the environment, and their willingness to purchase the product. The results suggest personality segmentation, through selective marketing and redirecting of consumers needs and wants toward environmentally friendly wine products. For example, what wine consumers actually know about environmental wine issues is associated with their involvement with environmental issues more than what they self-assess they know about wine.
\end{abstract}

Keywords: environmental knowledge, green products, wine

\section{Introduction}

During the past twenty years there has been a dramatic increase in environmental consciousness worldwide, with consumers changing their behavior to incorporate environmental considerations into lifestyle choices. These changes include consumers' purchasing decisions based upon how well products satisfy their needs and affect the natural environment. In many cases, consumers are willing to pay a premium for environmentally friendly products.

The impact that company and consumer activities have on natural resources and the environment in general have long been a consideration of marketers. ${ }^{1}$ In fact environmentalism has been designated as potentially the greatest consumer and business issue since the early 1990s. This surge of interest is affected by the realization that the world's supply of natural resources maybe limited and that the ecological balance of the environment can possibly be changed. ${ }^{2}$

The wine industry in the United States has, for example, increasingly faced pressure to improve its environmental performance, and is now beginning a transformation regarding implementation of environmentally safer practices. ${ }^{3}$ This transformation is the result of pressures wineries have encountered such as fines for violating the Clean Water Act, ${ }^{4}$ being stopped from expanding vineyard space due to endangered species, ${ }^{5}$ and issues with neighbors over the use of pesticides. ${ }^{3}$

These pressures increase the difficulties wineries must endure as the industry matures giving rise to industry trade groups, most notably the Wine Institute in 
California, developing codes of sustainable practices to enable its members to be responsive to these pressures. ${ }^{3}$

An area of importance to the wine industry is therefore placing their efforts toward identifying the ecologically oriented consumer through profiling. This concept can be found in the marketing literature as far back as the 1970 s. $^{6-9}$

Contributions to general literature dealing with ecologically conscious consumers evolved in academic areas such as sociology, ${ }^{10}$ education, ${ }^{11}$ and psychology. ${ }^{12}$ Overall, the results of these research studies found that demographic profiling by income, education and age and concern for the environment had been mixed. Other constructs such as involvement and personality measures of attitude were shown to be promising predictors of ecological concern. ${ }^{8}$

Consumer involvement refers to the feelings of interest, concern and enthusiasm held towards product categories and brands. It is an important concept in consumer marketing because it provides a basis for motivation, which can explain various behavioral outcomes of consumers.

Involvement with a product and environmental issues are important constructs when assessing consumers willing to purchase, with previous research emphasizing the importance of the relationship between product involvement and product knowledge. ${ }^{13-16}$ At the same time, recent studies have begun to understand the complexity of consumer behavior and environmental knowledge and how attitudes can affect such behavior. ${ }^{17}$

Strong attitudes regarding a social issue and product category can predict behavior. ${ }^{18}$ Krarup and Russell found that attitude is a better predictor of willingness to purchase the more knowledge the consumer has about the issue the greater the willingness to purchase the product. This is particularly true when there is a positive attitude toward performing an environmentally friendly act, such as buying a sustainable product. Yet no studies were found that considered the relationship of consumer involvement with a product and their attitudes about the environmental impact of the product.

Therefore, using wine as the product, the purpose of this study is to determine the relationship of a consumer's involvement with a product and the environment, their knowledge of environmental issues and attitudes toward the environment, and their willingness to purchase the product. The implications of this research to the wine industry could be vast. As consumers' knowledge of environmental issues increase, resulting in attitude change, their choice of a wine brand or even a wine region destination may be influenced by how the consumer perceives this industry's group environmental policies.

\section{Literature review}

The demand for environmentally friendly or "green" products has been shown to be uneven across different market segments. ${ }^{19,20}$ Thus, for organizations to position "green" products and services, or communicate their environmental efforts to consumers who are likely to be concerned about environmental issues, understanding of the environmentally conscious consumer is critical. The increase in environmental consciousness has had a profound effect on consumer behavior, with the "green" product market expanding at a remarkable rate.

For example, a survey in 1990 concluded that $27 \%$ of British adults were prepared to pay up to $25 \%$ more for "green" products, ${ }^{21}$ and in the USA, Green Market Alert estimated a market growth rate for "green" products of $10.4 \%$ in 1993 to $\$ 121.5$ billion, and projected that this will reach $\$ 154$ billion by $1997 . .^{22}$

In a recent study by GFK, ${ }^{23}$ four in ten Americans say they are willing to pay for a product that is perceived as being better for the environment. At the same time, 55\% agree that environmentally-safe products are not actually better for the environment and most say they are too expensive (74\%) and don't work as well or that quality is an issue (61\%).

Marketing often acknowledges that its purpose is to serve the good of society by informing consumers of the availability of goods and services which may improve their quality of life. Yet, this is only true if marketing's communication approach and methods of promotion assist in informing, educating and channeling the needs of all potential consumers toward "green" products and services.

There are three critical areas that marketing needs to consider in order to be effective in the environmental movement. First, is developing new strategies for sustainable marketing. These strategies should follow the three basic concepts outlined by of re-consumption of products, ${ }^{24}$ redirecting of consumers needs and wants toward environmentally friendly products, and reorientation of the product mix. This includes repackaging, relabeling, and repositioning. Second, repositioning needs to avoid the pitfalls of "green washing", which describes advertisements in which the environmental claims are trivial, misleading, or deceptive regarding the benefits of a product. ${ }^{15}$

Finally, marketing needs to put forth segmentation strategies. There has been a wealth of research using a variety of segmentation variables, attempting to profile the 
environmentally conscious members of the population in general. The measures that have been used fall into four distinct socio-demographic and demographic categories: sociodemographics, such as sex, age, education and social class, ${ }^{9,26}$ personality measures, such as ideological expressiveness, ${ }^{7,9,23}$ attitudes, such as, attitudes toward pollution and attitude toward ecologically conscious living, and finally consumption patterns such as ecologically responsible buying and usage of products.

Given the relative ease with which sociodemographics can be measured and applied, it is not surprising they have been the most widely used variables for profiling purposes. However, evidence illustrates that there is very little value in the use of sociodemographic characteristics alone for profiling environmentally-conscious consumers. ${ }^{9}$

Personality variables have been found to have somewhat higher linkages to individual's environmental consciousness. ${ }^{7,27}$ However, while this is true for general environmental measures, the results are somewhat inconsistent for specific pro-environmental behaviors, such as green purchasing decisions. ${ }^{9}$ Furthermore, personality variables have been shown to explain only a small part of the total variability of the behavioral measures. ${ }^{28}$ Indeed, Hooley and Saunders suggest that caution should be taken in using personality variables alone for market segmentation and in most instances, personality measures are most likely to be of use for describing segments once they have been defined on some other basis. ${ }^{29}$

Therefore, in order to position "green" product offerings, companies must first segment the market according to levels of pro-environmental purchase behavior and then target the "greener" consumer segments. This current study has selected six constructs for personality segmentation: environmental involvement, product involvement, objective and subjective environmental knowledge and environmental attitudes.

\section{Involvement}

The concept of involvement originated in research on political persuasion, ${ }^{30}$ with its application moving into other disciplines. ${ }^{16}$ Consumer behavior research began with a focus on involvement related to consumers' attitudes towards products. Zaichkowsky suggested involvement was the degree of perceived relevance of an object based on inherent needs, values, and interests. ${ }^{31}$ Rothschild described involvement as a motivational state of a buyer that determines the personal relevance of a purchase decision. ${ }^{32}$

Involvement theory views consumer behavior as a continuum covering a range of cognitive and behavioral processes. Mittal suggested consumers that are 'highly involved,' actively search for and process information to make informed product selections to satisfy their needs and wants, ${ }^{33}$ yet according to Kassarjian, a great deal of consumer behavior is low involvement and does not involve extensive information search and evaluation prior to purchasing. ${ }^{34}$

Thus, involvement is evoked differently depending upon various psychological stimuli. Andrews classified involvement research into four streams: attention/processing strategies, personal/situational involvement, audience/process involvement, and enduring/product involvement. ${ }^{35}$ Laurent and Kapferer also made an attempt to differentiate enduring/ situational involvement, emotional/rational involvement, and personal/solution involvement. ${ }^{36}$

Among them, enduring and situational involvement has been considered as a reasonable classification, with enduring involvement representing a permanent and general, long-term concern with perception of the product or issues that consumers bring to the situation, whereas, situational is related to the temporary feelings of involvement that results from a particular situation. ${ }^{37}$

Product involvement has been seen in prior literature in two different ways: as product importance ${ }^{38,39}$ and as enduring involvement. ${ }^{40}$ For example, the ongoing interest of a bicycle enthusiast in bicycle-related activities shows enduring involvement. Products that are hedonic or pleasure-related evoke enduring involvement. In contrast, largely practical products, such as a gas water heater, can have purchase importance without having enduring involvement.

\section{Enduring (product) involvement}

Recent research on product involvement includes works by Dodd and colleagues, Kolyesnikova and colleagues, So and Chakravarty, and Barber and colleagues. ${ }^{41-44}$ The view in these studies is that enduring involvement conceptualization, is the extent to which the consumer views purchasing and consuming the product and the purchase decision as a central, meaningful, significant, and engaging activity in their life.

Therefore, product involvement is a goal-oriented, emotional state of interest, enthusiasm, perceived relevance, and excitement consumers' exhibit towards a product category, which is based on needs, values and interest, ultimately influencing purchase or consumption of the product. ${ }^{16,32.38}$

Previous research analyzed the influences of product involvement on consumer attitudes, brand preferences, and perceptions. Depending on levels of involvement, consumers differ significantly on their purchasing quantities, ${ }^{45}$ perceptions of services, ${ }^{46}$ consumption, ${ }^{47}$ as well as satisfaction, store and salesperson trust. ${ }^{48}$ It is expected that product 
involvement may influence the consumers environmental concerns about wine production, therefore this study will use this construct to assess consumer product involvement.

\section{Enduring (environmental) involvement}

As discussed earlier, involvement has been defined as the relevance and importance a product has to consumers and their purchase decision. Concern over the environment has evolved through several distinct phases. From the 1960s ecology movement focusing on pollution and energy conservation, to the recent use of environmental issues as a source of competitive advantage in business and politics with individual and societal concerns over environmental issues becoming increasingly important. ${ }^{49}$

Numerous studies have addressed the characteristics of ecologically involved consumers either as a primary point of investigation or as a secondary issue. The majority of these studies have looked at, and found, demographic variables associated with self-report measures of environmental involvement, behavioral indicators of environmental involvement, or psychometric scales measuring environmental involvement. ${ }^{50,51}$ However, a review of the ecological concern literature indicates researchers have limited success in explaining the social basis of environmental behavior by simple correlation analysis. ${ }^{52}$ Further, other empirical findings do not support the existence of a "typical" consumer that is involved with conservation in either nonpurchase resource conservation behavior ${ }^{53}$ or in private purchase consumption patterns. ${ }^{9}$

Thus, the power of demographic and psychosocial variables in explaining environmental involvement is questionable. Nevertheless, the involvement-attitudebehavior hierarchy model, ${ }^{54,55}$ works by identifying how consumers in high-involvement situations combine their beliefs about product attributes to form attitudes about various brand alternatives or other objects. This model has proven its ability in explaining how personal values affect ecological attitudes on specific ecological issues (such as recycling) which in turn influence particular forms of ecological behavior (like recycling behavior).

\section{Environmental knowledge}

A key element of environmental conscious consumption is a desire by consumers for more information about the relationship between products and the environment, with greater exposure to "green" information sources influencing consumer purchasing decisions. ${ }^{20}$ According to a study by GFK, Americans have shifted to a more environmentally-conscious mind-set. ${ }^{23}$ Fifty percent of consumers say they do not have the information to be personally involved in increasing their green behavior and aren't sure which products and packaging materials are recyclable. Forty-nine percent state they would do more for the environment if they only knew how. In addition, $40 \%$ of Americans said they would be willing to pay more for a product that is perceived as being better for the environment.

However, to date, most research studies on environmental knowledge have examined only one or, ${ }^{56,57}$ at most, two forms of environmental knowledge. ${ }^{11,58}$ These studies do not comprehensively analyze the relative effects of different knowledge forms on behavior.

According to Peattie, attempts to explain purchase behavior have been related to a consumer's knowledge of green issues. Although difficult to prove, consumers that are knowledgeable about the environment will be motivated toward environmentally friendly purchase behavior. ${ }^{20}$ Martin and Simintiras found this to be a difficult relationship to prove with no clear link identified. ${ }^{59}$ Krause discovered the ability of consumers to answer questions on environmental issues correctly did not correlate with subjective environmental knowledge. ${ }^{60}$ The issue is the difficulty in measuring environmental knowledge and the inconsistency of translating this knowledge into consumer behavior.

Amyx and colleagues found that subjective environmental knowledge was a better predictor of ecological purchasing intentions than objective knowledge. In other words, consumers that think they know more about the environment are more likely to buy green products than those that actually knew about environmental issues. ${ }^{61}$

This disregard for completeness results in a lack of understanding in which different knowledge forms work together in promoting consumer behavior. ${ }^{62}$

\section{Attitude}

Attitudes are essential to consumer behavior research and marketing often seeks ways to determine and modify attitudes about products, brands, and services. The main focus has been that by understanding attitudes, market research can better predict consumer behavior, thereby changing consumers' attitudes to elicit an appropriate behavior.

Thus, one function of knowledge is to help maintain strong attitudes. Attitudes are typically considered strong when they are resistant to change and persistent over time. Thus, knowledgeable people with strong attitudes are careful, expert processors of information. Most analyses of an 
attitude's strength recognize that knowledge contributes to a high attitude level. Eagly and Chaiken suggested that strong attitudes are often thought to be constructed on an extensive, well organized knowledge framework that provides an informational basis for reactions to the "attitude object." 63

When considering the environment, increased knowledge is assumed to change environmental attitudes, and both environmental knowledge and attitudes are assumed to influence environmental purchase behavior. ${ }^{64}$ In a study on the relationship between environmental knowledge and environmental attitudes conducted by Bradley and colleagues, significant correlations were found between participant's attitudes and knowledge. ${ }^{65}$ They stated that the basis for many environmental problems and issues is irresponsible environmental behavior, and one of the most important influences on this behavior is attitude.

\section{Wine as a product}

Wine is an experiential consumer product that is difficult for a consumer to judge by looking at it. During the past fifteen years, wine has increasingly become a beverage most often consumed by those Americans that drink alcoholic beverages. ${ }^{66-69}$ The US is currently the 3rd largest nation in total wine consumption and may top the list in the next few years. ${ }^{70}$

In fact, the Wine Market Council found that between 2000 and 2005 the wine drinking population in the US increased by $31 \%$ among adults in households with an income greater than $\$ 35,000$, while the number of adults drinking beer and/or spirits decreased by $25 \% .{ }^{71}$ Wine is increasingly being chosen as an accompaniment to meals in 'casual chain' restaurants, and at home when all the family dines together. ${ }^{66-68}$

With this increase in demand and consumption, has been the significant increase in the number of vineyard acres planted and the number of wineries. As of November 2006, there were nearly 6,000 wineries in the US, up $26 \%$ from 2004. At the same time, the number of vineyard acres planted has risen to 934,750 grape-bearing acres in 2007.

Thus, with this increase in demand and expansion come issues of the environmental footprint that wineries have. Although the environmental performance of the wine industry does not receive as much media attention as industries often characterized as 'dirty' such as the chemical industry, it still faces a number of serious environmental issues and challenges. The wine industry must work to limit their use of toxic pesticides, herbicides and fertilizers or creating a scarcity of water supplies. They should also reduce the amount of contaminated wastewater run-off, organic wastes and nonhazardous packaging materials. ${ }^{3}$ In agricultural and semi-rural areas where residents depend on wells for drinking water these materials pose serious problems given the propensity for nitrates to leach into groundwater.

Wineries must also pay attention to land use issues involving habitat destruction and endangered species. These land use issues are further complicated by the rising tension in major wine producing regions of the US, such as Sonoma County, CA, where residents of local communities are concerned that wineries are overusing the remaining available tracts of land. ${ }^{71}$

Given these known environmental issues and the fact wine consumption is personal, this allows for testing distinct levels of product involvement, environmental involvement and knowledge while allowing for the examination of the influence attitude plays in the purchase decision process.

\section{Proposed model and hypothesized relationships}

This research proposes a segmentation approach through an analysis of the linkages between willingness to purchase behavior and measures of product involvement, environmental consciousness and knowledge. The rationale for this approach rests on the fact that consumers have traditionally been shown to express their environmental consciousness through the products they purchase. ${ }^{23}$

The model depicted in Figure 1 reflects the paths and the relationships between the constructs of environmental involvement, environmental knowledge and attitudes, enduring product involvement, all as independent variables and willingness to purchase as the dependent construct variable.

Previous research has explored direct effects of wine product involvement and wine product knowledge on consumer purchasing behavior. ${ }^{41,72}$ Research has demonstrated that involvement with a product category is an important determinant of consumer purchasing with the level of involvement in the purchase decision and the importance and intensity of the interest in a product critical to the purchase decision. ${ }^{73}$

Consumer behavior models reflect knowledge as a variable influencing all phases of the purchasing decision process. ${ }^{74,75}$ This knowledge is formed from a consumer's past product related consumption experience, ${ }^{76}$ and is most commonly the construct used to conceptualize the consumer's actual purchasing and usage behavior. ${ }^{77}$

However, little research has been found that discussed consumer involvement in environmental issues, their 


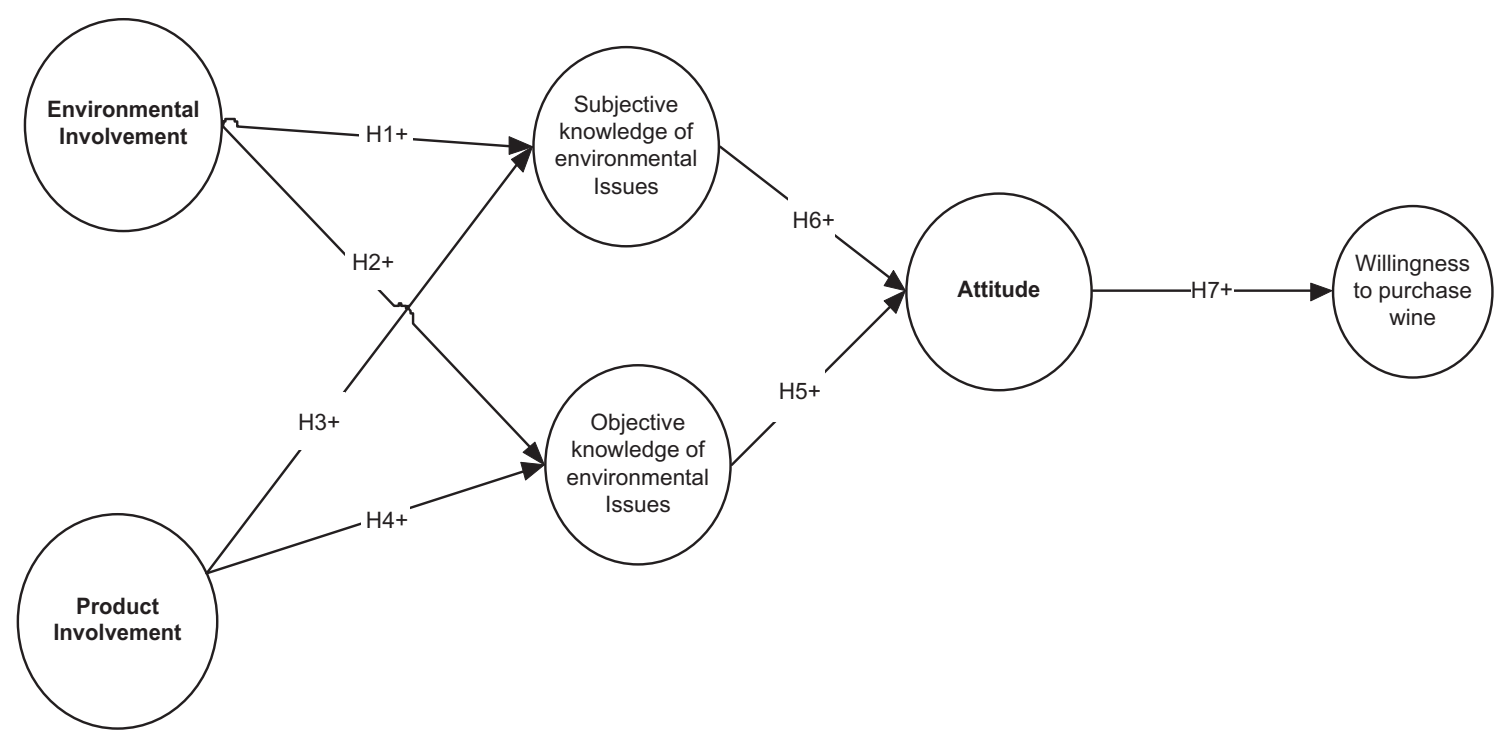

Figure I Proposed model.

knowledge of these issues, and the impact on purchase behavior. In a study by Bang and colleagues, they tested a theoretical framework by assessing the relationship of three variables (concern with the environment, knowledge about renewable energy, and consumers' attitude toward paying a premium for renewable energy). ${ }^{78}$

The current study extends the defined role of involvement, knowledge, and attitude by examining the three variables as predictors of purchase behavior. Our model posits that involvement, knowledge, and attitude can influence the willingness to purchase.

It is expected that depending on levels of product involvement, environmental knowledge and involvement, consumers would differ in their willingness to purchase environmentally friendly wine. Highly involved and knowledgeable customers are usually more discriminating in their choices. For such customers, certain aspects of their shopping behavior are particularly important, for example having access to an assortment of products or knowledgeable sales personnel, as well as informative advertisements or news reports.

Therefore, we hypothesize the following relationship: $\mathrm{H}_{1}$ : Involvement with environmental issues will have a significant positive association with objective environmental wine knowledge.

$\mathrm{H}_{2}$ : Involvement with environmental issues will have a significant positive association with subjective environmental wine knowledge.

For hypotheses 1 and 2, we assumed that the relationship will be strongest with objective knowledge. Prior research on objective and subjective knowledge and involvement has been mixed in studies other than environmental research. The nature of involvement dictates its close relationship with the amount of knowledge consumers have in relation to a particular product category (ie, high involvement equates with higher knowledge).

According to Zaichkowsky and Bang and colleagues, ${ }^{78,79}$ when an issue involves personal importance or values, it enhances involvement. This information search may result in higher levels of consumer knowledge about alternative solutions to environmental problems such as alternative products. Accordingly, we would expect that those people have enduring product involvement with wine and who are more concerned about the environment are more likely to be knowledgeable about environmental wine production or other environmentally friendly alternatives to conventional production. Therefore for hypotheses 3 and 4, we propose the following:

$\mathrm{H}_{3}$ : Product involvement will have a significant positive association to subjective environmental wine knowledge.

$\mathrm{H}_{4}$ : Product Involvement will have a significant positive association to objective environmental wine knowledge.

Arcury indicated that knowledge was assumed to change attitudes.${ }^{64}$ Previous research by Bradley and colleagues and Eagly and Chaiken on the relationships between environmental knowledge and environmental attitudes were found to be significantly correlated between participant's attitudes and knowledge. Therefore, we hypothesize the following relationships: ${ }^{63,65}$ 
$\mathrm{H}_{5}$ : Objective environmental wine knowledge will have a significant positive association with attitude toward the environment.

$\mathrm{H}_{6}$ : Subjective environmental wine knowledge will have a significant positive association with attitude toward the environment.

Previous research suggests that subjective and objective knowledge influence information processing in different ways. In particular, objective knowledge is more likely to influence the amount of information sought, whereas subjective knowledge is closely related to purchase-related behaviors, attitudes, and purchasing decisions. For example, Amyx and colleagues found that subjective environmental knowledge was a better predictor of green purchasing intentions than objective knowledge. ${ }^{61}$ Therefore, given the above, for hypothesis 7, we propose:

$\mathrm{H}_{7}$ : Attitude toward the environment will have a significant

positive association with willingness to purchase environmentally friendly wine.

To summarize, as mapped in Figure 1, we assume that consumer product involvement, environmental involvement and knowledge and environmental attitudes will influence the willingness to purchase by customers.

\section{Methodology \\ Design of the study}

The sample for this study, a self-selected nonprobability, judgment sample, was drawn from across diverse geographic locations in the US. The URL link was sent to the over 2,400 members of the society of wine educators, which include 135 members from foreign countries and members representing 43 states and the District of Columbia. The Society of Wine Educators, which was founded in 1974, is a nonprofit educational organization. The Society's goal is to foster and promote the professional education and development of the individual in particular, and the professional education and development of the wine industry as a whole. The survey links were distributed in September 2008 with a total of 820 questionnaires collected resulting in a $42 \%$ response rate. Membership in the society is represented by various professions, such as educators, importers, distributors, producers, retailers, restaurateurs, and hoteliers. Although this sample represents most of the states, members of this society are individuals that are highly involved with wine as a product and thus may not represent the entire population of the US (see limitations at end of study).

\section{Measures}

\section{Product involvement}

Product involvement was measured by the modified version of the Personal Involvement Inventory scale originally developed by Zaichkowsky. ${ }^{16,33}$ Indicators of product involvement were "unimportant/important; means nothing to me/means a lot to me; insignificant/significant; does not matter to me/matters to me," each assessed by a seven-point bipolar scale.

\section{Environmental involvement}

Following the work of Mittal and Zaichkowsky, ${ }^{16,33}$ this construct was measured by modifying the product involvement questions to address the environment. Indicators of environmental involvement were "unimportant /important; means nothing to me/means a lot to me; insignificant/ significant; does not matter to me/matters to me," each assessed by a seven-point bipolar scale.

\section{Environmental objective knowledge}

This construct was measured by asking respondents about their environmental wine knowledge. The instrument construction followed environmental wine knowledge questions developed in previous studies modified to wine production. ${ }^{80,81}$

\section{Environmental subjective knowledge}

This construct was measured by asking respondents how they perceive their environmental wine knowledge. The instrument construction followed subjective environmental knowledge questions developed in previous general product studies by Amyx and colleagues and wine studies by Dodd and colleagues and Barber. ${ }^{41,61,81}$ Three seven-point bipolar scale questions were used in this study each anchored between very little (1) and very much (7), measured participants self-reported assessment of product knowledge: "How much do you feel you know about environmental issues?"; "Compared to your friends and acquaintances, how much do you feel you know about environmental issues?" and "Compared to an environmental expert, how much do you feel you know about environmental issues?"

\section{Environmental attitude}

Following work by Arcury, Campbell, and Armstrong and Impara, the attitude inventory consisted of four questions rated on a Likert-type scale. ${ }^{64,82,83}$ The questions dealt with general attitudes regarding the environment and were anchored by 1 (strongly disagree) and 7 (strongly agree). Indicators of environmental attitude were "The ecological crisis" 
facing the world has been greatly exaggerated, "Mankind is severely abusing the environment." "The balance of nature is very delicate and easily upset," and "Humans need not adapt to the natural environment because they can remake it to suit their needs." This last statement was reverse coded.

\section{Willingness to purchase}

Following a study conducted by Cornwall and Schwepker, where they tested the purchase intentions (PI) of environmental products, this study used four similar statements to test willingness to purchase an environmentally produced wine. The questions were anchored by 1 (strongly disagree) and 7 (strongly agree). ${ }^{27}$ Indicators of willingness to purchase included "I would pay any price for a wine product as long as it was environmentally safe" and "I would switch from my usual wine brand and buy environmentally safe wine, even if I give up some quality."

Following Churchill's recommendations for scale development and to gain information about the data collection process and the questionnaire, a pilot study was conducted. ${ }^{84}$ The primary purpose was to determine whether the instrument could be clearly understood by respondents and ensure reliability of the instrument. For the pilot test, an Internet link to the instrument was emailed to 60 individuals in Texas, Massachusetts, North and South Carolina, New Mexico, and New York during the week of August 18, 2008. Cronbach's alpha coefficients were used for the item scales ranging from a low of 0.70 for environmental attitude to a high of 0.98 for product involvement. The full factor analysis accounted for $89.5 \%$ of the total variance, with only one factor loading less than 0.73 .

Based upon the high reliability of this pilot study, it was decided not to perform a second pilot test. An analysis of the pilot respondents' demographics did not reveal any unusual characteristics that would require modification of the survey.

\section{Data analysis}

Statistical analysis was computed using the Windows versions of Statistical Package for Social Sciences (Version 15.0, SPSS Inc., Chicago, IL, USA) and AMOS (Analysis of Moment Structures, release 7.0/SPSS 15.0). Structural equation modeling testing centered on two basic concepts: validating the measurement model, then testing, fitting and modification of the structural model. The first is achieved through confirmatory factor analysis and the latter completed through path analysis. ${ }^{85}$ As suggested by Tabachnick and Fidell, construct items were restricted to their respective factors but allowed to correlate with the other constructs. ${ }^{85}$

Structural equation modeling was performed because of its unique ability to examine the simultaneous interactions that are hypothesized by the constructs in the proposed model (Figure 1) and because it provides values that aid in the determination of how well the hypothesized models fit the data set.

\section{Results Descriptive statistics}

Fifty-one percent of the respondents were male $(n=419)$ and $49 \%$ were female $(n=401)$. The average age of respondents was 45 years. Respondents had high levels of education with $79 \%$ of the sample having earned a college degree. Sixty-one percent of the respondents had annual household income above $\$ 80,000$, with $25 \%$ over $\$ 140,000$.

Overall, the sociodemographic background of all respondents (middle-aged, educated, with higher incomes) mirrored the profile of wine consumers in general, ${ }^{86}$ and were similar to data collected in surveys conducted by Barber and Kolyesnikova. ${ }^{81,87}$ Following regional designations by the United States government, ${ }^{88}$ the respondents were grouped accordingly, with $48 \%$ from the southern region and $28 \%$ from the western region of the US.

The average number of years respondents reported consuming wine was 29. The average number of bottles $(750 \mathrm{ml})$ purchased per respondent was 19 per month, with the average amount spent during this same period $\$ 435$, or $\$ 23$ per bottle. When asked how much they would spend for an environmentally made wine, the respondents reported \$27 per $750 \mathrm{ml}$ bottle, or $\$ 4$ more than they normally would pay for a bottle of wine, suggesting there is a perception of quality and value associated with environmentally made wine.

Respondents reported moderate levels of subjective environmental knowledge $(M=4.3, S D=1.3)$, indicating they considered themselves somewhat knowledgeable about environmental issues. Interestingly, they considered themselves much more knowledgeable than friends $(M=4.9, S D=1.2)$ and much less so than environmental experts $(M=3.6, S D=1.4)$. As for environmental attitudes, respondents had a strong overall attitude $(M=4.9, S D=1.8)$ that the environment was in trouble, with the strongest feeling that mankind was severely abusing the environment $(M=5.1$, $S D=1.8)$, and wineries were not doing enough to protect it $(M=5.5, S D=1.1)$.

When asked about wine production and the environmental impact to the planet, respondents considered the use 
of pesticides, herbicides, and fungicides an important issue $(M=5.6, S D=1.4)$ and the use of nonrecyclable packaging $(M=4.8, S D=1.8)$. The least important was the impact to the entire globe through transporting and shipping of wine $(M=3.8, S D=1.8)$.

When asked which wine bottle closure was better for the environment, respondents considered recyclable natural cork ( $M=5.3, S D=1.4$ on a 7-point scale), followed by natural cork $(M=4.8, S D=1.6)$ and metal screw caps $(M=4.2, S D=1.5)$. Those closures respondents considered worst for the environment were synthetic corks $(M=2.9, S D=1.3)$ and plastic screw caps $(M=3.1, S D=1.4)$. Interestingly, those with high environmental involvement $(M=5.5, S D=1.4)$ were significantly more likely to find recycled cork products better for the environment than those with low environmental involvement $(M=4.9, S D=1.5), t(849)=2.88, p<0.02$, while those with low environmental involvement $(M=3.5, S D=1.4)$ considered plastic screw cap closures to better for the environment significantly more than did those with high environmental involvement $(M=2.9, S D=1.3), t(849)=2.57, p<0.03$.

\section{Data reduction and analysis of hypotheses model}

Following the procedure suggested by Anderson and Gerbing and Ryu and Jang, data were analyzed using the two-step approach in which the measurement model was first confirmed and then the structural model was tested. ${ }^{89,90}$ In the first step, a confirmatory factor analysis (CFA) was performed to identify whether the measurement items reliably reflected the a priori latent constructs (product involvement, environmental involvement, objective and subjective environmental knowledge, attitude and willingness to purchase). An examination of factor loadings, eigenvalues greater than one, and the scree plot suggested six factors. These six factors accounted for $78 \%$ of the total variance.

Following the work by Ryu and Jang, ${ }^{90}$ Cronbach's alphas, item reliabilities, composite reliabilities, and average variance extracted (AVE) were computed (Table 1). All factor loading scores were above 0.75 , indicating acceptable internal consistency. ${ }^{91,92}$

Cronbach's alpha for the constructs ranged from 0.75 to 0.95, while the composite reliabilities ranged from 0.78 to 0.97 . In summary, the measurement of the specified model showed good evidence of reliability and validity. Using SEM procedures, the hypothesized model (Figure 1) was tested to establish and confirm the model. The results of the standardized parameter estimates and significance values are shown in Table 2.
The first step in assessing a model fit is to examine its chi-square $\left(\mathrm{X}^{2}\right)$. The $\mathrm{X}^{2}$ goodness-of-fit statistic assesses the magnitude of discrepancy between the sample and fitted covariance matrices, and it is the product of the sample size minus one and the minimum fitting function. When the proper assumptions are met (large sample size and assumption of multivariate normality) the chi-square will he relatively small and the $\mathrm{p}$ value associated with it was relatively large. It has been found, however, that with large sample sizes the chi-square may prove to be contradictory compared to other goodness of fit indexes. ${ }^{93-95}$

These researchers have considered the limitations of $\mathrm{X}^{2}$ by developing goodness-of fit indexes that take a more pragmatic approach to the evaluation process with fit indexes that have been offered to supplement the $\mathrm{X}^{2}$ test. A fit index can be used to quantify the degree of fit along a continuum and classified into absolute and incremental fit indexes. An absolute fit index assesses how well an a priori model reproduces the sample data. Examples of absolute fit indexes include the Goodness-of-Fit Index (GFI) and the Adjusted Goodness-of-Fit Index (AGFI) and the root mean square error of approximation (RMSEA).

Based upon the model-fit-indices $\left(\mathrm{X}^{2} / d f=5.5, \mathrm{GFI}=0.93\right.$, $\mathrm{CFI}=0.94$, and RMSEA $=0.07)$, the model provided a reasonably good fit to the data. As shown in Figure 2, the causal relations between product involvement and objective and subjective environmental wine knowledge suggests that the more involvement with a product, directly enhances subjective environmental knowledge $(\beta=0.07, p<0.04)$ or the belief in what one thinks they know about environmental wine issues, and reduces objective environmental knowledge $(\beta=-0.08, p<0.02)$.

Environmental involvement related positively with objective environmental knowledge $(\beta=0.42, p<0.00)$ and subjective environmental knowledge $(\beta=0.17, p<0.00)$, with objective environmental the strongest relationship. Subjective environmental knowledge related negatively with attitude $(\beta=-0.11, \mathrm{p}<0.01)$, while objective environmental knowledge related positively, and more strongly with attitudes $(\beta=0.37, \mathrm{p}<0.00)$ than subjective knowledge. Finally, attitude related positively to willingness to purchase $(\beta=0.27, p<0.00)$, indicating that stronger attitudes towards environmental issues can influence a consumers purchase behavior toward environmentally friendly wine.

\section{Discussion}

The hypothesized model was tested along with the seven research hypotheses postulated to evaluate how product 
Table I Scale items and confirmatory factor analysis results for the hypothesized model $(\mathrm{N}=820)$

\begin{tabular}{|c|c|c|c|c|}
\hline $\begin{array}{l}\text { Constructs } \\
\text { (Cronbach's Alpha) }\end{array}$ & $\begin{array}{l}\text { Target factor } \\
\text { loading }\end{array}$ & $\begin{array}{l}\text { Item } \\
\text { reliabilities }\end{array}$ & $\begin{array}{l}\text { Composite } \\
\text { reliabilities }\end{array}$ & AVE \\
\hline Product involvement (0.94) & & & 0.93 & 0.92 \\
\hline Wine to me means a lot & 0.96 & 0.91 & & \\
\hline Wine to me is significant & 0.95 & 0.91 & & \\
\hline Wine to me matters & 0.92 & 0.85 & & \\
\hline Environmental involvement (0.95) & & & 0.95 & 0.87 \\
\hline Environment to me matters & 0.91 & 0.83 & & \\
\hline Environment to me is significant & 0.90 & 0.82 & & \\
\hline Environment to me means a lot & 0.87 & 0.76 & & \\
\hline Subjective environment knowledge $(0.85)$ & & & 0.87 & 0.84 \\
\hline How much did you feel you know & 0.90 & 0.81 & & \\
\hline Compared to a wine expert & 0.87 & 0.76 & & \\
\hline Compared to my friends & 0.84 & 0.71 & & \\
\hline Objective environment knowledge $(0.87)$ & & & 0.89 & 0.85 \\
\hline Using excessive energy & 0.90 & 0.81 & & \\
\hline Creating uncontrolled water run-off & 0.89 & 0.79 & & \\
\hline Impacting underground water & 0.87 & 0.76 & & \\
\hline Creating scarcity of water & 0.86 & 0.74 & & \\
\hline Creating organic wastes & 0.80 & 0.64 & & \\
\hline Using nonrecyclable packaging & 0.77 & 0.59 & & \\
\hline Attitude $(0.75)$ & & & 0.80 & 0.80 \\
\hline The balance of nature is delicate & 0.87 & 0.76 & & \\
\hline Mankind is severely abusing environment & 0.84 & 0.71 & & \\
\hline Humans need to adapt to the natural environment & 0.80 & 0.64 & & \\
\hline Willingness to purchase $(0.80)$ & & & 0.75 & 0.75 \\
\hline I would pay any price & 0.82 & 0.67 & & \\
\hline I would change brands with reduced quality & 0.81 & 0.66 & & \\
\hline Environmental advertisements impact my purchase & 0.76 & 0.58 & & \\
\hline
\end{tabular}

Note: Nontarget factor loadings were all below 0.45 .

involvement, environmental involvement, knowledge, and attitude influence purchasing decisions. Hypotheses 1 and 2 proposed that involvement with the environment would have a positive causal relationship with the knowledge constructs of objective and subjective environmental wine knowledge. This was supported with causal relationships with the strongest relationship with objective knowledge, suggesting that with increases in general environmental involvement, objective environmental wine knowledge would increase, while subjective environmental wine knowledge increased at a much lesser extent.

The implication here is that what wine consumers actually know about environmental wine issues is more closely associated with their involvement with environmental issues than with what they believe they know about wine. In other words, higher general environmental involvement builds wine environmental wine knowledge. These results support early studies by Arcury and colleagues, and Bradley and colleagues, where they found that increased; well organized knowledge framework strongly influences attitudes. ${ }^{63-65}$
Hypotheses 3 and 4 reported mixed results. Hypothesis 3 was supported with weak yet significant causal relations between product involvement and subjective environmental wine knowledge. However, hypothesis 4 was not supported with a negative association with product involvement and objective knowledge. This suggests that involvement with wine as a product will positively impact a consumer's belief in what they know about environmental wine issues. Though Park and Lessig acknowledge that both subjective and objective knowledge measures are valid, they suggest that subjective measures is a better measure of consumer strategies and behavior because it is based upon perceptions, of what consumers think they know about a product. ${ }^{96}$

When considering product involvement with wine, Raju and colleagues, Dodd and colleagues, and Barber and colleagues found that subjective knowledge was a better predictor of purchasing behavior than was objective knowledge. ${ }^{41,46,72}$

Finally, Hypotheses 5 and 6 also had mixed results. Hypothesis 6 was supported with strong and significant 
Table 2 Standardized coefficients and p-values for hypothesized model $(\mathrm{N}=820)$

\begin{tabular}{|c|c|c|c|}
\hline Hypothesized path & $\begin{array}{l}\text { Standardized } \\
\text { coefficients path }\end{array}$ & P-value & Hypotheses \\
\hline Attitude $\rightarrow$ Willingness to purchase & 0.27 & $0.00 * *$ & $\mathrm{H}_{7}:$ Supported \\
\hline Subjective knowledge $\rightarrow$ Attitude & -0.11 & $0.01 *$ & $\begin{array}{l}\mathrm{H}_{6}: \text { Not } \\
\text { supported }\end{array}$ \\
\hline Objective knowledge $\rightarrow$ Attitude & 0.37 & $0.00 * *$ & $\mathrm{H}_{5}:$ Supported \\
\hline Product involvement $\rightarrow$ Objective knowledge & -0.08 & $0.02 *$ & $\begin{array}{l}\mathrm{H}_{4}: \text { Not } \\
\text { supported }\end{array}$ \\
\hline Product involvement $\rightarrow$ Subjective knowledge & 0.07 & $0.04 *$ & $\mathrm{H}_{3}:$ Supported \\
\hline Environmental involvement $\rightarrow$ Subjective knowledge & 0.17 & $0.00 * *$ & $\mathrm{H}_{2}:$ Supported \\
\hline Environmental involvement $\rightarrow$ Objective knowledge & 0.42 & $0.00 * *$ & $\mathrm{H}_{1}$ : Supported \\
\hline
\end{tabular}

Notes: $* p<0.05 ; * * p<0.01$

Overall goodness-of-fit comparisons for the specified model

\begin{tabular}{|c|c|c|c|c|c|c|c|c|c|}
\hline Model & $\mathbf{X}^{2}$ & $d f$ & $\mathrm{X}^{2}$ ratio & $p$ & GFI & AGFI & NFI & CFI & RMSEA \\
\hline No mediating model & 787.07 & 144 & 5.47 & 0.00 & 0.93 & 0.90 & 0.92 & 0.94 & 0.07 \\
\hline
\end{tabular}

Abbreviations: GFI, Goodness-Of-Fit Index; AGFI, Adjusted Goodness-Of-Fit Index; NFI, Normed Fit Index; CFI, Comparative Fir Index; RMSEA, root mean square error of approximation.

positive relationship with objective environmental wine knowledge and attitude, suggesting that the greater wine consumers' actual environmental wine knowledge, the greater their overall attitude towards general environmental issues. Arcury suggested that strong objective knowledge plays a key role in developing environmental attitudes. ${ }^{64}$ However, these results are counter to those found by Amyx and colleagues, where they suggested that subjective knowledge was a better predictor of behavior. ${ }^{61}$
Hypothesis 5 was not supported with a negative and significant relationship between subjective environmental wine knowledge and attitudes. This suggests that subjective environmental wine knowledge may decrease a wine consumer's attitude toward environmental issues

Finally, hypotheses 7 was supported with a strong and significant relationship between attitude and willingness to purchase environmentally friendly wine, suggesting that respondents with strong attitudes will consider

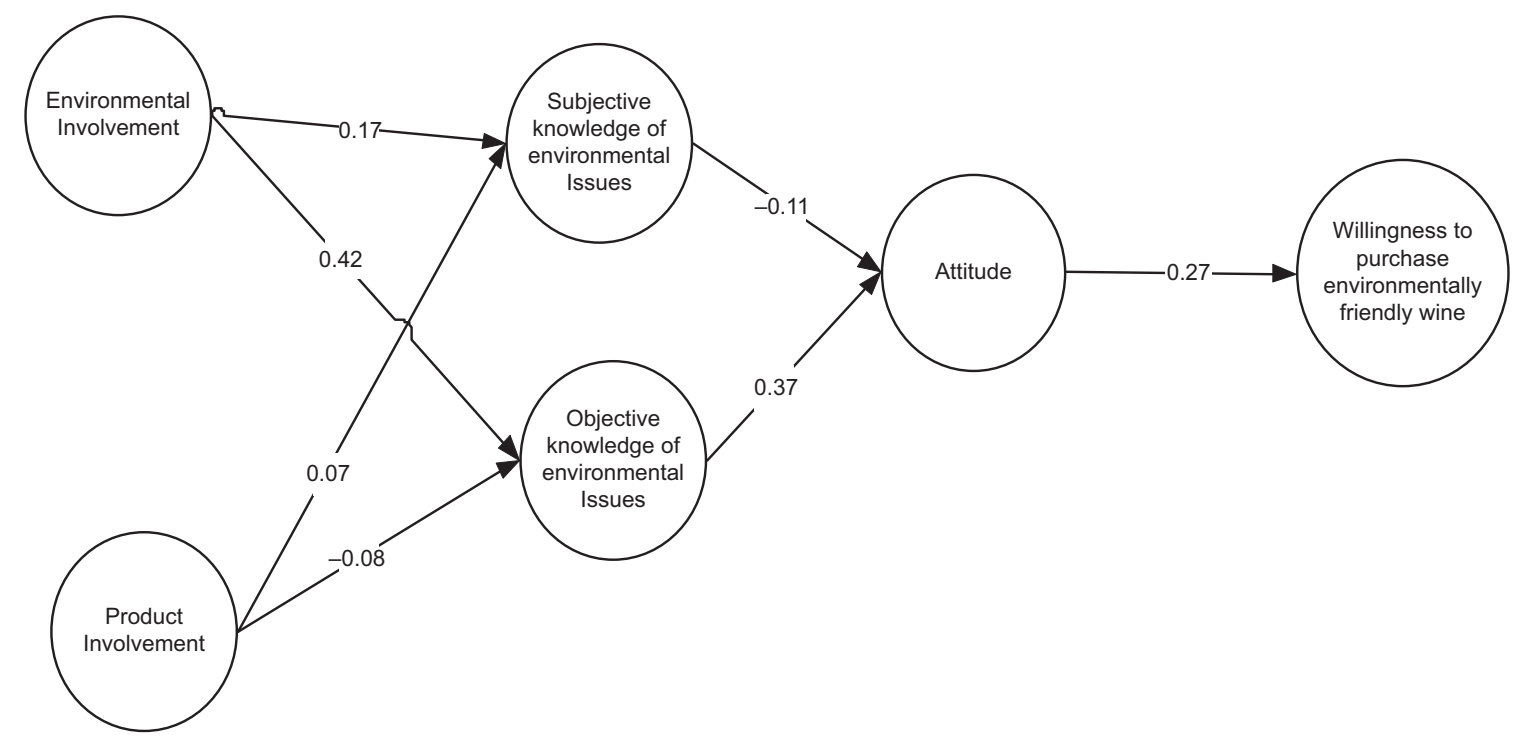

Figure 2 Hypothesized model showing standardized path estimates. 
environmentally friendly wine, supporting work by GFK where they found Americans were willing to pay more for a product that was beneficial to the environment. ${ }^{23}$

The results suggest that while the respondents typically spend more money on an average bottle of wine (\$23) than respondents in wine studies by Barber and colleagues (\$15) and Dodd and colleagues (\$18), they would be willing to spend more on a wine (\$27) purported to be environmentally friendly. Further, those that reported strong attitudes would be willing to pay even more (\$30) for a bottle of environmentally friendly wine..$^{41,96}$

\section{Managerial implications}

The success of a marketing model inherently lies in the ability to determine variables that differentiate consumer's performance in the marketplace. Based on the findings of this study, it can be concluded that segments which are defined by having different levels of actual environmental involvement and knowledge are distinct segments of the population which differ in a range of other personal characteristics as well. They can consequently be used to implement selective marketing approaches aiming at attracting environmentally conscious wine consumers. In times of major ecological changes where the global negative impact of human behavior on the environment can no longer be denied, any additional measure that can help reduce negative environmental impacts is valuable. Selective marketing is one additional tool that can be included in the environmentally sustainable management toolbox, but many other tools could be developed.

For example, knowledge is an important link to perceived product importance, which is defined by Bloch and Richins, ${ }^{97}$ as the extent to which a consumer ties a product and its attributes to relevant purchase situation-specific goals (usage). A published work by $\mathrm{Hu}$ and Bruning tested the extent to which product importance is relevant to discriminating among types of airline travelers. This same concept of product importance can be applied to wine consumers. ${ }^{98}$

The results of this study showed that style of closure was an important product attribute of those respondents based upon their level of environmental involvement, with plastic screw tops considered better for the environment by low involved respondents and recycled natural cork closures by high involved respondents. To provide target segments with appropriate products, wine producers must tap into the consumers' reason why they choose to purchase or drink wine, which should guide packaging designers to appropriately meet consumers' expectations, thereby taking into account the cues that packaging transmits (recycled cork is better for the environment), instead of just focusing on positioning the product through short-lived messages transmitted by the media.

Another approach would be to profile light, medium and heavy spenders in an attempt to assess whether an expenditure based segmentation approach could be beneficial to wine producers. It has been demonstrated in this and other studies that wine consumers would be willing to pay more for an environmentally friendly wine..$^{21,64}$ Thus an important part of this approach would be developing new strategies for ecological marketing by the redirecting of consumers needs and wants toward environmentally friendly wine products, such as organic wines, and reorientation of the product mix through repackaging and re-labeling.

\section{Limitations and future research}

One limitation is the sampling method. The sample was a nonprobabilistic sample from geographically diverse groups known to the researchers. Although the individuals were independently and randomly selected from each group, the results of this research may not be generalized to the entire population.

Another possible limitation is the halo effect. A halo effect occurs when consumers assume that because a product is good or bad on one product concern for the characteristic, such as environmental concern about wine production and pesticide use, it is also good or bad on another product characteristic.

A suggestion for future research would be to consider the environmentally friendly wine consumer. This can be accomplished by following the suggestions of Arcury by segmenting consumers into gender, income, age and education, thereby allowing for selective marketing to these groups. ${ }^{64}$

\section{Disclosure}

The authors report no conflicts of interest in this work.

\section{References}

1. Jay L. Green about the tills: Markets discover the eco-consumer. Manage Rev. 1990;79:24-29.

2. Hayes D. The Green Decade. Amic J. 1990;12:24-29.

3. Marshall R, Cordano M, Silverman M. Exploring individual and institutional drivers of proactive environmentalism in the US wine industry. Business Strategy and the Environment. 2005;14:92-109.

4. Fish T. Viader fined by Napa County for environmental violations. Wine Spectator. 2002. [Cited August 15, 2008]. Available from http://www. winespectator.com/Wine/Daily/News/0\%2C1145\%2C1584\%2C02. html.

5. Fish T. Sierra Club tries to block new Beringer complex in Napa. Wine Spectator. 2002; Jan 18. p. 17.

6. Anderson T, Cunningham W. The socially conscious consumer. J Mark. 1972;36:23-33.

7. Kinnear H, Taylor J, Ahmed S. Ecologically concerned consumers: Who are they? J Mark. 1974;38:20-24. 
8. Antil J. Socially responsible consumers: Profile and implications for public policy. Journal of Micromarketing. 1984;4:18-32.

9. Balderjahn I. Personality variables and environmental attitudes as predictors of ecologically responsible consumption patterns. J Bus Res. 1988; 17:51-56.

10. Buttel F. New directions in environmental sociology. Ann Rev Sociol. 1987;13:465-488.

11. Hines J, Hungerford H, Tomera A. Analysis and synthesis of responsible environmental behavior: A meta-analysis. J Environ Educ, 1987;13:1-8.

12. Arbuthnot J. The roles of attitudinal and personality variables in the predication of environmental behavior and knowledge. Environ Behav. 1977;9:217-232.

13. Maclnnis DJ, Mooreman C, Jaworski BJ. Enhancing and measuring consumers' motivation, opportunity, and ability to process brand information from ads. J Mark. 1991;55:32-53.

14. Petty RE, Cacioppo JT. Communication and persuasion: Central and peripheral routes to attitude change. New York: Springer; 1986.

15. Wright P. Cognitive responses to mass media advocacy. In: Petty RE, Ostrom TM, Brock TC, editors. Cognitive Responses in Persuasion. Hillsdale, NJ: Lawrence Erlbaum; 1981. p. 263-282.

16. Zaichkowsky JL. Familiarity: Product use, involvement, or expertise? Adv Consum Res. 1985;12:296-299.

17. Frick J, Kaiser F, Wilson M. Environmental knowledge and conservation behavior: Exploring prevalence and structure in a representative sample. Pers Individ Diff. 2004;37:1597-1613.

18. Krarup S, Russell C. Environment, information and consumer behavior. Cheltenham, UK: Edward Elgar Publishing Limited; 2005.

19. Ottman JA. Green Marketing: Challenges and Opportunities for the New Marketing Age. Lincolnwood, IL: NTC Business Books; 1992.

20. Peattie K. Environmental Marketing Management: Meeting the Green Challenge. London: Pitman Publishing; 1995.

21. Prothero A. Green consumerism and the societal marketing concept marketing strategies for the 1990s. J Mark Manage. 1990;6:87-103.

22. Lawrence J. Green product sprouting again: more focused efforts avoid controversy. Advert Age. 1993;10:12.

23. GFK. Americans reach environmental turning point: Companies need to catch up. Custom Research North America. 2007. [Cited Aug 25 , 2008]. Available from http://www.prnewswine.com/cgi-bin/stories pl?acct=104\&story=/www.story/08-22-207/00046497348\$edate\#link toppagebottom.

24. Polansky MJ, Mintu-Wimsatt AT, editors. Environmental Marketing: Strategies, Practice, Theory, and Research. Binghamton, NY: The Hawthorn Press; 1995.

25. Carlson L, Kangun N, Grove S. A classification schema for environmental advertising claims: Implications for marketers and policy makers. In: Polansky MJ, Mintu-Wimsatt AT, editors. Environmental Marketing: Strategies, Practice, Theory, and Research. Binghamton, NY: The Hawthorn Press; 1995. p. 225-238.

26. Schlegelmilch B, Bohlen G, Diamantopoulos A. The link between green purchasing decisions and measures of environmental consciousness. Eur J Mark. 1996;30:35-55.

27. Cornwall B, Schwepker C. Ecologically concerned consumers and their product purchase. In: Polansky MJ, Mintu-Wimsatt AT, editors. Environmental Marketing: Strategies, Practice, Theory, and Research. Binghamton, NY: The Hawthorn Press; 1995. p. 119-153.

28. Webster F. Determining the characteristics of the socially conscious consumer. J Consum Res. 1975;2:188-196.

29. Hooley GJ, Saunders J. Competitive Positioning: The Key to Marketing Strategy. London: Prentice-Hall International; 1993.

30. Sherif M, Cantril H. The Psychology of Ego-involvements, Social Attitudes and Identifications. New York, NY: Wiley and Sons, Inc; 1947.

31. Zaichkowsky JL. Measuring the involvement construct. J Consum Res. 1985;12:341-352.

32. Rothschild ML. Perspectives on involvement: Current problems and future directions. Adv Consum Res. 1984;1:216-217.
33. Mittal B. Measuring purchase decision involvement. Psychol Mark. $1989 ; 6: 147-162$

34. Kassarjian H. Low involvement: a second look. Adv Consum Res. 1981;8:31-34.

35. Andrews JC. Motivation, ability, and opportunity to process information: Conceptual and experimental manipulation issues. Adv Consum Res. 1988;15:219-225.

36. Laurent G, Kapferer J. Measuring consumer involvement profiles. J Mark Res. 1985;22:41-53.

37. Houston M, Rothschild M. Conceptual and methodological prospectives of involvement, In: Jain S, editor. 1978 Educators' Proceedings. Chicago, IL: American Marketing Association; 1978. p. 184-187.

38. Hupfer NT, Gardner DM. Differential involvement with products and issues: An exploratory study, Paper presented at the Second Annual Conference of the Association for Consumer Research, College Park, $\mathrm{MD} ; 1971$.

39. Lastovicka J. Questioning the concept of involvement defined product classes. Adv Consum Res. 1979;6:174-179.

40. Bloch P. An exploration into the scaling of consumers' involvement with a product class. Adv Consum Res. 1981;8:61-65.

41. Dodd T, Laverie D, Wilcox J, Duhan D. Differential effects of experience, subjective knowledge, and objective knowledge on sources of information used in consumer wine purchasing. Journal of Hospitality and Tourism Research. 2005;29:3-19.

42. Kolyesnikova N, Dodd TH, Wilcox JB. Gender differences as antecedents to reciprocal consumer behavior. J Consum Mark. 2009;26: In Press.

43. Yuan J, So SI, Chakravarty S. To wine or not to wine: profiling a wine enthusiast for a successful list. Journal of Nutrition in Recipe and Menu Development. 2005;3(3/4):63-79.

44. Barber N, Ismail J, Dodd T. Purchase attributes of wine consumers with low involvement. Journal of Food Products Marketing. 2007;14:69-86.

45. Lockshin LS, Spawton AL, Macintosh G. Using product, brand and purchasing involvement for retail segmentation. Journal of Retailing and Consumer Services. 1997;4:171-183.

46. Dodd TH, Gustafson WA. Product, environmental, and service attributes that influence consumer attitudes and purchases at wineries. Journal of Food Products Marketing. 1997;4:41-59.

47. Goldsmith RE, d'Hauteville F, Flynn LR. Theory and measurement of consumer innovativeness: A transnational evaluation. Eur J Mark. 1998;32:340-353.

48. Lockshin L, Quester PG, Spawton AL. Segmentation by involvement or nationality for global retailing: A cross-national comparative study of wine shopping behaviours. J Wine Res. 2001;12:223-236.

49. Straughan R, Roberts J. Environmental segmentation alternatives: a look at green consumer behavior in the new millennium. $J$ Consum Mark. 1999;16:531-532.

50. Samdahl D, Robertson R. Social determinants of environmental concern: specification and test of the model. Environ Behav. 1989;21:57-81.

51. Zimmer M, Stafford T, Stafford M. Green issues: dimensions of environmental concern. J Bus Res. 1994;30:63-74.

52. Van Liere KD, Dunlap RE. The social bases of environmental concern: a review of hypotheses, explanations and empirical evidences. Public Opin Q. 1980;181-197.

53. Pickett GM, Kangun N, Grove SJ. Is There a general conserving consumer? a public policy concern. Journal of Public Policy and Marketing. 1993;12:234-243.

54. Holmer P, Kahle L. A structural equation test of the value-attitudebehaviour hierarchy. J Pers Soc Psychol. 1988;54:638-646.

55. McCarthy JA, Shum LJ. The recycling of solid wastes: personal values, value orientations, and attitudes about recycling as antecedents of recycling behaviour. J Bus Res. 1994;30:53-62.

56. Gambro JS, Switzky HN. Variables associated with American high school students' knowledge of environmental issues related to energy and pollution. J Environ Educ. 1999;30:15-22. 
57. Leeming FC, Dwyer WO, Bracken BA. Children's environmental attitude and knowledge scale: Construction and validation. J Environ Educ. 1995;26:22-31.

58. Schultz PW. Knowledge, information, and household recycling: Examining the knowledge-deficit model of behavior change. In: Dietz T, Stern PC, editors. New tools for environmental protection: Education, information, and voluntary measures. Washington, DC: National Academy Press; 2002. p. 67-82.

59. Martin B, Simmintiras A. Determination of green purchase behavior: A review of the literature and an agenda for further research. In: Bell J, et al. editors. Marketing: Unity and Diversity. Proceedings of the 1994 Marketing Educators Group Conference; 1994. p. 628-637.

60. Krause D. Environmental consciousness. Environ Behav. 1993;25:126-142.

61. Amyx D, DeJong P, Lin X, Chakrabotry G, Wiener L. Influencers of purchase intentions for ecologically safe products: An exploratory study. Marketing Theory and Applications, Proceedings on the 1994 AMA Winter Educators Conference; 1994. p. 341-347.

62. Kaiser FG, Fuhrer U. Ecological behavior's dependency on different forms of knowledge. Appl Psychol. 2003;52:598-613.

63. Eagly A, Chaiken S. The Psychology of Attitudes, New York: Harcourt Brace; 1993.

64. Arcury T. Environmental Attitude and Environmental Knowledge. Human Organization. 1990;49:300-304.

65. Bradley J, Waliczek T, Zajicek J. Relationship between environmental knowledge and environmental attitude of high school students. J Environ Educ. 1999;30:17-22.

66. Jones J. U S drinkers consuming alcohol more regularly. 2006. [Cited Nov 5, 2007]. Available from: http:/www.gallup.com/poll/23935/USDrinkers-Consuming-Alcohol-More-Regularly.aspx

67. Jones J. Beer again edge out wine as American drink of choice. 2007. [Cited Nov 1, 2007]. Available from: http://www.gallup.com/ poll/28234/Beer-Again-Edges-Wine-Americans-Drink-Choice.aspx

68. Saad L. Wine gains momentum as Americans' favorite adult beverage. The Gallup Poll Survey, July 18, 2005. [Cited Oct 17, 2007]. Available from: http://www.gallup.com/search/default.aspx?q=beverage+survey+ gallop $\& \mathrm{~s}=\& \mathrm{~b}=\mathrm{SEARCH}$.

69. Wine Institute. 2005 California wine sales continue growth trend as wine Enters mainstream U S. lifestyle. 2006. [Cited April 3, 2006]. Available from: http://www.wineinstitute.org/industry/statistics/2006/ wine_sales.php.

70. Hussain M, Cholette S, Castaldi R. Determinants of wine consumption of US consumers: an econometric analysis. Int $J$ Wine Bus Res. 2007;19:46-62.

71. Baughman AT, Brown EJ, Brummet W, Dramko JM, Goldstein JH, Hooper BE. California Winemaking Impact Assessment, Masters Thesis. Santa Barbara, CA: University of California - Santa Barbara; 2000.

72. Raju P, Lonial S, Mangold W. Differential effects of subjective knowledge, objective knowledge and usage experience on decision making: An exploratory investigation. J Consum Psychol. 1995;4:153-180.

73. Orth UR, Firbasova Z. The role of consumer ethnocentrism in food product evaluation. Agribusiness. 2003;19:137-153.

74. Beatty S, Smith S. External search effort: An investigation across several product categories. J Consum Res. 1987;14:83-96.

75. Brucks M. The effects of product class knowledge on information search behavior. J Consum Res. 1985;12:1-16.

76. Alba J, Hutchinson J. Dimensions of consumer expertise. J Consum Res. 1987;13:411-454.

77. Bettman J, Park C. Effects of prior knowledge and experience and phase of the choice process on consumer decision processes: A protocol analysis. J Consum Res. 1980;7:234-248.
78. Bang HK, Ellinger A, Harjimarcou J, Traichal P. Consumer concern, knowledge, belief, and attitude toward renewable energy: An application of the reasoned action theory. Psychology and Marketing. 2000;17:449-468.

79. Zaichkowsky JL. The emotional aspect of product involvement. $A d v$ Consum Res. 1987;14:32-35.

80. Arcury TA, Johnson TP, Scollay SJ. Ecological Worldview and Environmental Knowledge: An Examination of the "New Environmental Paradigm." J Environ Educ. 1986;17:35-40.

81. Barber N. How self-confidence and knowledge effects the sources of information selected during purchase situations. Published dissertation. Lubbock, TX: Texas Tech University; 2008.

82. Campbell AN. The attitude and knowledge relationships between secondary agriculture and science students' participation in multidisciplinary education and environmental/wetland restoration. Master's thesis. College Station, TX: Department of Horticultural Sciences, Texas A\&M University; 1994.

83. Armstrong JB, Impara JC. The impact of an environmental education program on knowledge and attitude. J Environ Educ. 1991;22:36-40.

84. Churchill GA. Basic Marketing Research, 5th ed. Mason, OH: SouthWestern; 2004.

85. Tabachnick B, Fidell L. Using Multivariate Statistics. Boston: Allyn and Bacon; 2001. p. 57-85 (Data samples); p. 653-771 (Structural Equation Modeling).

86. Motto K, Fisher L. US Wine Demographics Report. St. Helena, CA: The Wine Business Center; 2000.

87. Kolyesnikova N. Gratuity purchasing at wineries: The role of gratitude and obligation in purchase by winery visitors. Unpublished Dissertation. Lubbock, TX: Texas Tech University; 2006.

88. United States Government. The United States Government. 2008. [Cited Oct 2, 2008]. Available from: http://www.fbi.gov/ucr/cius 02/ $\mathrm{html} / \mathrm{web} / \mathrm{appendices} / 07$-append03.html $\& \mathrm{~h}=332 \& \mathrm{w}=651 \& \mathrm{sz}=24 \& \mathrm{tb}$ nid=5Fcg47klieYJ::\&tbnh=70\&tbnw=138\&prev=/images $\% 3 \mathrm{Fq} \% 3 \mathrm{D}$ regions $\% 2$ Bof $\% 2$ Bthe $\% 2$ Bunited $\% 2$ Bstates $\&$ hl=en $\&$ usg $=\ldots F 3$ ga $1 \mathrm{c}$ HK2WixwzbCjhO3IM7UX9o=\&sa $=X \&$ oi $=$ image_result\&resnum $=5$ \&ct=image $\& \mathrm{~cd}=1$.

89. Anderson J, Gerbing D. Structural equation modeling in practice: A review and recommended two-step approach. Psychol Bull. 1988;103:411-423.

90. Ryu K, Jang S. The effect of environmental perceptions on behavioral intentions through emotions: The case of upscale restaurants. Journal of Hospitality and Tourism Research. 2007;3:56-72.

91. Hair J, Anderson R, Tatham R. Black W. Multivariate Data Analysis, 5th ed. Upper Saddle River, NJ: Prentice Hall; 1998.

92. Byrne B. Structural Equation Modeling with AMOS. Mahwah, NJ: Lawrence Erlbaum Associates; 2001.

93. Hu L, Bentler P. Cutoff criteria for fit indexes in covariance structure analysis: Conventional criteria versus new alternatives. Structure Equation Modeling, 1999;6:1-55.

94. Schumacker R, Lomax R. A Beginner's Guide to Structural Equation Modeling. Mahwah, NJ: Lawrence Erlbaum Associates; 2004.

95. Park C, Lessig P. Familiarity and its impacts on consumer decision biases and heuristics. J Consum Res. 1981;8:144-151.

96. Barber N, Taylor C, Dodd T. The importance of wine bottle closures in retail purchase decisions of consumers. Journal of Hospitality Marketing and Management. 2008;18:(4) In Press.

97. Bloch P, Richins M. A Theoretical model for the study of product importance perceptions. J Mark. 1983;47:69-81.

98. $\mathrm{Hu} \mathrm{M}$, Bruning E. Decomposing instrumental product importance to predict purchase behavior. Journal of Travel Research. 1986;25:24-28. 